\title{
Establishment of in Direct Propagation of Mandarin (Citrus reticulata L.) Using Tissue Culture
}

\author{
Awatef M. E. Badr-Elden\# \\ Plant Biotechnology Department, Genetic Engineering \& Biotechnology Research Institute \\ (GIBRI), University of Sadat City, Egypt.
}

\begin{abstract}
$\mathrm{T}$ HE PRESENT investigation deals with development of an efficient micropropagation protocol for mandarin (Citrus reticulata L.) via in direct propagation using cotyledons and juice vesicles as explant. The establishment of in vitro callus induction from leaf, stem segments and cotyledon system were excised from seedlings has been done. Best results for induction of callus were observed from cotyledons and stem segments $100 \%$ on MS medium supplemented 1 or $2 \mathrm{mg} / 1$ 2,4-D. MS medium supplemented with $300 \mathrm{mg} / 1$ glutamine or $1.5 \mathrm{mg} / 1$ casein hydrolysate proved to be the most efficient additive in promoting callus formation from juice vesical with $4.22,4.23 \mathrm{~g} /$ callus fresh weight, $100 \%$ response and was the most favorable medium. Maximum callus fresh weight $(7.96 \mathrm{~g})$ and $100 \%$ response were obtained from juice vesicles when cultured on MS medium supplemented with $2 \mathrm{mg} / 12,4-\mathrm{D}$ and $10 \%$ coconut water. The highest callus regeneration and weight of callus observed from juice vesicles by adding $2 \mathrm{mg} / 1$ 2,4-D, 300 or $400 \mathrm{mg} / 1$ malt extract. Callus raised from juice vesicles showed maximum shoots $(96.67 \%)$ with $0.5 \mathrm{mg} / 1 \mathrm{Kin}, 400 \mathrm{mg} / 1 \mathrm{malt}$ extract and $2 \mathrm{mg} / 1 \mathrm{NAA}$. Regenerated shoots raised from juice vesicles showed better shoot multiplication and highest length of shoots on MS medium with $2 \mathrm{mg} / 1 \mathrm{BA}$ and $0.4 \mathrm{mg} / 1 \mathrm{NAA}$. Regenerated shoots were rooted on MS medium supplemented with different concentrations of NAA and best response (98\%) was observed with NAA ( $2 \mathrm{mg} / \mathrm{l})$ and gave maximum, roots number, roots length and leaves number. Rooted plantlets were successfully acclimatized with survival rate reaching almost $87 \%$. These plants grew normally without showing any morphological variation. Developed protocol can be useful for application of somatic embryogenesis from juice vesicles to improve mandarin.
\end{abstract}

Keywords: Casein hydrolyzed, Coconut water, Glutamine, In vitro, Juice vesicles, Malt extract, Mandarin, Rooting and adaptation.

\section{Introduction}

Citrus belongs to family Rutaceae having 150 genera and 15,000 species and it is distributed mostly in tropical and temperate region of the planet (Ladaniya, 2008). It has high dietary value and is a prosperous source of vitamin $\mathrm{C}$ in combination with macromolecules such as amino acids, organic acids and sugar as well as minerals comparable to magnesium and calcium in sufficient quantity (Niaz et al., 2004). Slow growth, long juvenility, insects, pests, diseases, alternate bearing, pre-and post-harvest losses, large number of seeds per fruit, short season of supply and short storage life are the problems facing by citrus species too (Mukhtar et al., 2005). One of the effective methods for citrus propagation is the use of somatic embryogenesis which consequently produces a large number of healthy uniform plants (Gholami et al., 2013).
Somatic embryogenesis is an efficient protocol of plant regeneration and rapid propagation of large number of plants within a short time. In vitro plant culture has used as a tool for propagation and improvement of many plant species including citrus. In citrus, the production of embryogenic callus lines was reported from excised undeveloped ovules (Starrantino \& Russo, 1980), juice vesicles (Nito \& Iwamasa, 1990), anthers (Benelli et al., 2010), from immature seeds separated from immature fruits (Gholami, 2013) and from leaves, epicotyls, cotyledons (Kiong et al., 2008). The presence of cytokinin, in concentrations up to 2 $\mathrm{mg} / \mathrm{l}$, stimulated the in vitro organogenesis when internodal segments-derived explants were used for Citrus limonia and Citrus aurantium. Although no statistic differences could be detected, culture media supplementation with the combination of BAP and NAA favored the development of adventitious shoots in Citrus aurantium (Schinor

\#Corresponding author email: awatef.badrelden@gebri.usc.edu.eg

DOI :10.21608/ejbo.2017.799.1050

C2017 National Information and Documentation Center (NIDOC) 
et al., 2011). Micropropagation of citrus offers rapid propagation of such crops in limited space and time under controlled conditions around the year (Usman, 2005). Tissue culture is the best option to produce disease free seedling of the fruit crop rapidly. Micro-propagation and use of the in-vitro grafting (micro-grafting) is very helpful for production of virus free planting materials in mandarin (Amgai et al., 2016). Malt extract promoted germination of early cotyledonary stage embryos arising from the in vitro rescue of zygotic embryos of sour orange (Carimi et al., 1998). Sugar type and concentration had effects on citrus somatic embryo development. The combination of sorbitol (36.5 mM) with galactose $73 \mathrm{mM}$ was able to augment citrus somatic embryo maturation more effectively than the other concentrations applied (Widoretno et al., 2017). The aim of this research was to determine the best explant type (leaf, stem segments, and cotyledons) and growth regulator and natural additives in order to achieve callus induction. Simple quick response to indirect organogenesis was the main purposes for the use of (juice vesicles and cotyledons) in order to obtained healthy and uniform shoots and rooting of regenerated shoots.

\section{Materials and Methods}

This study was carried out during the period from 2014 to 2016 in the Laboratory of Gene Transfer and Germplasm Conservation, Department of Plant Biotechnology and plant material certified immature fruits (90 days after anthesis) were chosen from 10 years old Mandarin (Citrus reticulata L.) grafted tree was obtained from the farm at Genetic Engineering and Biotechnology Research Institute (GEBRI), University of Sadat City, Egypt.

\section{Surface sterilization}

Mandarin fruits were surface-sterilized by soaking in $10 \%$ commercial bleach (containing 5 $\%$ active chloride) for $20 \mathrm{~min}$, followed by three rinses with sterile distilled water. Fruits were then dipped in $95 \%$ ethanol and flamed for a few seconds. After flamed fruits were cut into two halves for seeds collected and juice vesicles were carefully separated for callus induction (Xiao et al., 2004).

\section{In vitro seed germination}

Surface sterilized of seeds were placed individually in 350 culture jar containing $30 \mathrm{ml}$ of liquid medium (Murashige \& Skoog, 1962) (MS) supplemented with $400 \mathrm{mg} / \mathrm{l}$ glutamine, $100 \mathrm{mg} / \mathrm{l}$ ascorbic acid, $30 \mathrm{~g} / 1$ sucrose and $7 \mathrm{~g} / \mathrm{l}$ agar. The seeds were maintained at $25 \pm 2{ }^{\circ} \mathrm{C}$ in the dark for three weeks, followed by one week under a $16-\mathrm{h}$ photoperiod 3000 lux. After 5 weeks' explants, (leaf, stem segments and cotyledons) were excised for callus induction.

\section{Callus induction}

Effect of dichlorophenoxy acetic acid (2, 4-D) concentrations and different explant parts on callus induction

Different explants like leaf, stem segments and cotyledons $(0.5-1.0 \mathrm{~cm})$ were excised from 5 weeks old in vitro raised nucellar seedlings for callus induction. Callus was initiated in $350 \mathrm{ml}$ culture jars containing $30 \mathrm{ml}$ of MS medium supplemented with $2,4-\mathrm{D}(0.0,0.5,1,2$ or $3 \mathrm{mg} / \mathrm{l})$. Explants were incubated in darkness, in a growth room $25 \pm 2^{\circ} \mathrm{C}$ for one month for two times. Data was recorded as percentage of callus induction and callus fresh weight (g/explant).

Effect of different additive on callus induction from juice vesicles and cotyledons

According to the results of previous experiment, $2 \mathrm{mg} / 1$ 2, 4-D were used to run this experiment. Cotyledons and juice vesicles $(1-2 \mathrm{~cm})$ excised from fruits were grown on MS medium contained 0, 100, 200 and $300 \mathrm{mg} / 1$ glutamine, 0.0, 0.5, 1.0 and $1.5 \mathrm{mg} / \mathrm{l}$ casein hydrolysate. One explant was cultured in $150 \mathrm{ml}$ a glass jar medium; contained $30 \mathrm{ml}$ each treatment had ten replicates. Data were recorded after two months for two times as callus fresh weight (g/explant) and percentage of callus induction.

Effect of different concentrations of coconut water on callus induction

Explants (juice vesicles and cotyledons) which produced with best response from above experiments were used to run this experiment to improvement of callus. Explant were cultured on MS medium containing 2mg/12,4-D and $0,5,10$ or $20 \%$ (v/v) coconut water. One explant $(1 \mathrm{~cm})$ was cultured in $150 \mathrm{ml}$ a glass jar medium; contained $30 \mathrm{ml}$ each treatment had ten replicates. Data were recorded after two months for two times as callus fresh weight (g/explant) and percentage of callus induction.

Effect of malt extract on callus regeneration

The juice vesicles and cotyledons derived callus $1 \mathrm{~cm}$ were obtained from above experiment and transferred to MS medium supplemented 
with $0.3 \mathrm{mg} / 1 \alpha$-naphthalene acetic acid (NAA), $0.5 \mathrm{mg} / \mathrm{l} \mathrm{BA}$ and different concentrations of malt extract $(0.0,100,200,300$ and $400 \mathrm{mg} / \mathrm{l})($ Carimi et al., 1998) and 30g/l sucrose. One explant was cultured in $150 \mathrm{ml}$ a glass jar medium; contained $30 \mathrm{ml}$ each treatment had ten replicates. The explants were maintained at $25 \pm 2{ }^{\circ} \mathrm{C}$ in dark. Data recorded after two months as callus fresh weight (g/explant) and percentage of regenerated of callus.

Effect of different concentration of NAA on in direct organogenesis from callus derived from juice vesicles and cotyledons

Callus regeneration from malt extract experiment were used as explants for in direct organogenesis. Regenerated callus was cultured on MS supplemented with $400 \mathrm{mg} / 1$ malt extract, $0.5 \mathrm{mg} / \mathrm{l} \mathrm{Kin}, 30 \mathrm{~g} / \mathrm{l}$ sucrose and different concentrations of NAA $(0.0,0.5,1.0,1.5$ and $2.0 \mathrm{mg} / 1)$ and $6 \mathrm{~g} / \mathrm{l}$ agar. The culture explants were kept under dark at $25 \pm 2^{\circ} \mathrm{C}$. Data were recorded after two months for two times as percentage of shoots induction.

Effect of $2 \mathrm{mg} / \mathrm{l}$ BA combination with different concentrations of NAA on shoot multiplication

The shoots excised from above experiment were inoculated on MS medium supplemented with 2mg/l BA combination with different concentrations of NAA $(0.0,0.1,0.2,0.4 \mathrm{mg} / \mathrm{l})$. The cultures were kept in culture room at 2000 lux and $25 \pm 2^{\circ} \mathrm{C}$. For each of the treatment, three explants in culture jar $350 \mathrm{ml}$ each $50 \mathrm{ml}$ of medium and ten replicate were used and the experiment was repeated two times. The number of shoots per explant and length of shoot $(\mathrm{cm})$ were observed after four weeks from culture.

\section{Rooting and acclimatization \\ Effect of different concentrations of auxins on root formation}

Shoots obtained from above experiment were transferred to MS supplemented with $0.5 \mathrm{mg} / \mathrm{K} \mathrm{Kin}$ for elongation of plantlets for one month and then transferred to different concentrations of Indole3-butyric acid (IBA) and (NAA) (0, 0.5, 1.0, 1.5 and $2 \mathrm{mg} / \mathrm{l}$ ) for rooting. Rooting of all the shoots were examined after six weeks as percentage of rooting, roots number, roots length $(\mathrm{cm})$ and plant length $(\mathrm{cm})$.

\section{Acclimatization of plants}

Rooted plants were transferred into $7 \mathrm{~cm}$ cup containing a mixture of peat moss and perlite (3:1, $\mathrm{v} / \mathrm{v})$. Plants were placed in greenhouses at $27 \pm$ $2^{\circ} \mathrm{C}$ under a $16 \mathrm{~h}$ photoperiod at 4000 lux. Plants were covered with transparent plastic lid cover to prevent water loss. Plants were fertilization with NPK every one week for two months and adapted plants was recorded as survival percentage.

\section{Layout of the experiments}

All experiments were designed in factorial completely design and data were compared according to method described by Steel \& Torrie (1980).

\section{Results and Discussion}

Effect of 2, 4-D concentrations on callus induction from different explant parts

In this experiment, callus induction was done fromleaves, cotyledons and stem segments explants were taken from five weeks from germinated seed. High efficiency callus was produced at $2 \mathrm{mg} / \mathrm{l} 2$, 4-D than other concentrations (Table 1 and Fig.1), the color of the callus produced was whitish and yellowish white. The development and maximum of callus induction percentage was observed at cotyledons and stem explants than leaf (97.33). The lower concentration of $2,4-\mathrm{D}(0.5 \mathrm{mg} / \mathrm{l})$ is not sufficient to induction of callus from leaves $(31.66 \%)$ but the same concentration sufficient to induce callus from cotyledons and stem (95 and $85 \%$, respectively). This phenomenon suggests that 2,4-D concentration and explant type are more important role in callus formation from explants. The results are in conformity with some of the earlier studies on different Citrus spp. which showed good callus induction response under the influence of in different concentrations 2,4-D. Altaf et al. (2009) reported that hormonal combination for good callus induction for seedling leaf of kinnow mandarin is $\mathrm{BA}+\mathrm{GA}$ (each at $1 \mathrm{mg} / \mathrm{L})+2,4-\mathrm{D}$ at $0.5 \mathrm{mg} / \mathrm{L}+$ proline at $5 \mathrm{mg} / \mathrm{L}$. Amin \& Shekafandeh (2015) found that MS medium supplemented with $0.5 \mathrm{mg} / 1$ 2,4-D induced maximum embryogenic calli of mexican lime. The best response for primary callus induction of kinnow mandarin $(90 \%)$ was obtained when MS medium was supplemented with $5 \mathrm{mg} / \mathrm{l}$ 2,4-D and $500 \mathrm{mg} / \mathrm{l}$ malt extract (Hussain et al., 2016). Mahadi et al. (2016) showed that the best a combination of hormones is treatment D2B2 (2 mg/1, 2,4-D, dan $2 \mathrm{mg} / \mathrm{l} \mathrm{BAP})$ producing embryogenic callus of Calamansi (Citrus microcarpa). 
TABLE 1. Effect of MS medium supplemented with different concentrations of 2, 4-D on percent of callus induction from leaf, cotyledons and stem segment excised from 6weeks old seedlings of Citrus reticulata L. (Observations recorded after 30 days for two times).

\begin{tabular}{|c|c|c|c|c|}
\hline \multirow{3}{*}{ 2,4-D con. (mg/l) } & \multicolumn{4}{|c|}{ Percent callus induction } \\
\hline & \multicolumn{3}{|c|}{ Explant type } & \multirow[b]{2}{*}{ Mean } \\
\hline & Leaf & Cotyledons & Stem segment & \\
\hline 0.0 & 15.00 & 6.66 & 5.00 & 8.88 \\
\hline 0.5 & 31.66 & 95.00 & 85.00 & 75.55 \\
\hline 1.0 & 88.33 & 100.00 & 100.00 & 96.11 \\
\hline 2.0 & 95.00 & 100.00 & 100.00 & 98.33 \\
\hline 3.0 & 53.33 & 95.00 & 88.00 & 78.77 \\
\hline Mean & 65.66 & 97.33 & 75.60 & \\
\hline LSD at $5 \% \mathrm{~A}$ & \multicolumn{4}{|c|}{3.96} \\
\hline B & \multicolumn{4}{|c|}{3.06} \\
\hline $\mathrm{AxB}$ & \multicolumn{4}{|c|}{6.86} \\
\hline
\end{tabular}

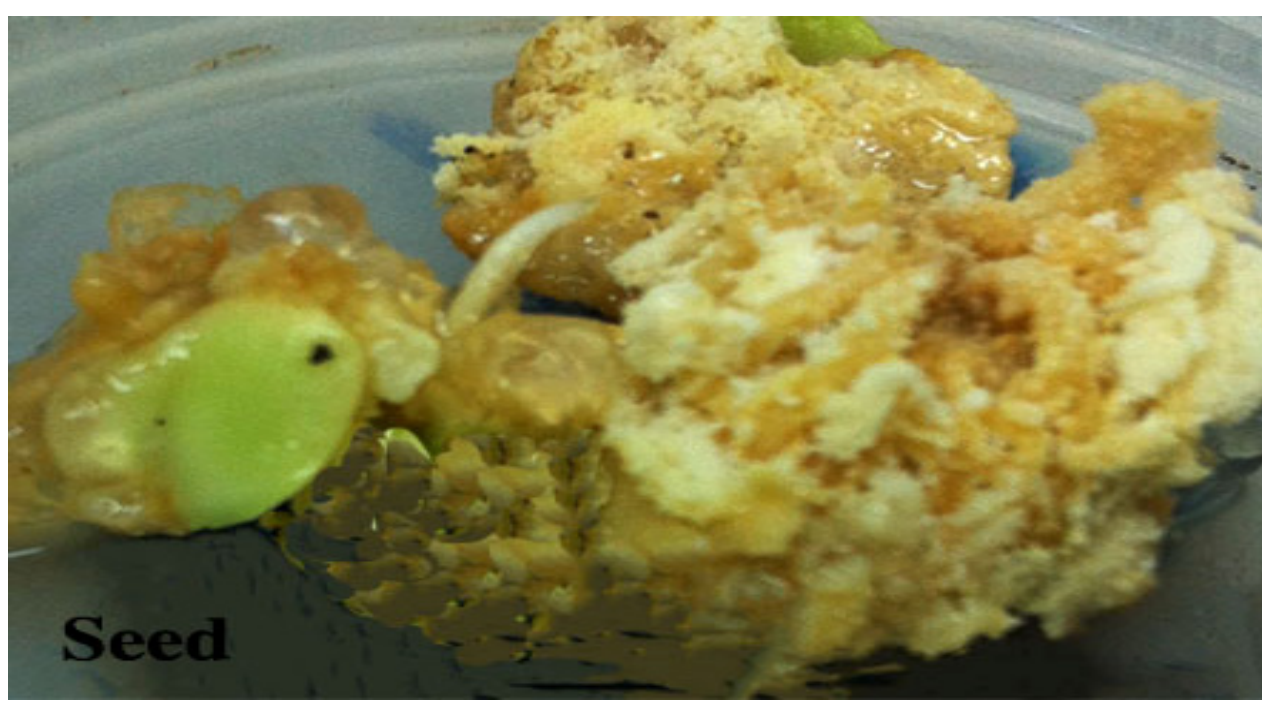

Fig. 1. Callus induction from seed on MS medium supplemented with 2mg/l 2, 4-D.

Effect of different additive on callus induction from Juice vesicles and cotyledons

Micropropagation via embryogeneic callus has become a vital mean for propagating of mandarin. Optimization of the culture medium may require some supplements other than plant growth regulators, which are normally added to the nutrient medium. It is clear from the reported data in Table 2 found that $300 \mathrm{mg} / 1$ glutamine and $1.5 \mathrm{mg} / 1$ cazen hydrolyseat has increased callus fresh weight and callus induction \% when supplemented to the callus maintenance medium. Juice vesicles exhibited a synergistic positive impact on callus fresh weight and callus induction \%, more than seeds explants. Maximum callus fresh weight and callus \% observed on $300 \mathrm{mg} / \mathrm{l}$ glutamine or $1.5 \mathrm{mg} / 1$ cazen hydrolyseat at juice vesicles than cotyledons as showed in Fig 2. Glutamine plays an important role in nitrogen assimilation as it is an intermediate in the transfer of ammonia into amino acid. Casein hydrolysate was found to be best medium composition for regeneration protocol developed from suitable explant for callus induction of mandarin. Some studies report mixture of amino acids (like Casein hydrolysate), rather than a single amino acid, as very supportive for shoot multiplication even in prolonged cultures (Nasir et al., 2011). Produced calli from Mexican lime juice vesicles are totipotent for embryogenesis and plant regeneration (Amin \& Shekafandeh, 2015).

Effect of different concentrations of coconut water on callus improvement

The effects of different concentrations of 
coconut water on embryogenesis fresh weight and improvement of callus \% are summarized in Table 3. Maximum callus fresh weight (g) produced on a medium containing $10 \%$ coconut water at juice vesicles explants (Fig.3) than callus derived from cotyledons. Moreover, minimum callus weight and callus induction $\%$ were produced at cotyledons than juice vesicles explants. This study shows that the, type of explant and concentrations of coconut water has a very significant effect on callus fresh weight and callus improved \%. Coconut water has a very significant effect on callus weight and callus induction $\%$. The results are agreement who those, The use combination of growth hormones and inclusion of other in vitro callus induction and proliferation factors, such as coconut (Cocos nucifera L.) extracts (Michael, 2007). Coconut water contains mainly water (94\%) and growth promoting substances that can influence in vitro cultures including inorganic ions, amino acids, organic acids, vitamins, sugars, sugar alcohols, lipids, nitrogenous compounds and phytohormones (Young et al., 2009). Shoot isolates that proliferated from calli at higher coconut water levels were able to grow to maturity (Michael, 2011).

TABLE 2. Effect of modified MS medium supplemented with glutamine and casein hydrolysate at different concentrations and different explant type on callus fresh weight (g) and callus percentage. (Observations recorded after two months for two times).

\begin{tabular}{|c|c|c|c|c|c|c|c|}
\hline \multirow{3}{*}{\multicolumn{2}{|c|}{$\begin{array}{l}\text { Different addative conc. } \\
\mathrm{mg} / \mathrm{l}\end{array}$}} & \multicolumn{3}{|c|}{ Callus fresh weight (g) } & \multicolumn{3}{|c|}{ Callus \% } \\
\hline & & \multicolumn{6}{|c|}{ Explant type } \\
\hline & & $\begin{array}{c}\text { Juice } \\
\text { vessels }\end{array}$ & Cotyledons & Mean (B) & Juice vessels & Cotyledons & $\begin{array}{l}\text { Mean } \\
\text { (B) }\end{array}$ \\
\hline \multirow{4}{*}{ Glutamine } & $\cdot, \cdot$ & 2.16 & 1.33 & 1.65 & 10.00 & 8.00 & 9.16 \\
\hline & 100 & 4.39 & 2.49 & 3.44 & 90.00 & 81.66 & 85.83 \\
\hline & 200 & 3.61 & 2.86 & 3.24 & 95.00 & 86.66 & 90.83 \\
\hline & 300 & 4.22 & 3.00 & 3.61 & 100.00 & 98.33 & 99.16 \\
\hline \multirow{4}{*}{$\begin{array}{l}\text { Casein } \\
\text { hydrolysate } \\
\text { Mean (A) }\end{array}$} & 0.5 & 3.13 & 1.80 & 2.46 & 53.33 & 76.66 & 65.00 \\
\hline & 1.0 & 3.60 & 2.56 & 3.08 & 65.00 & 100.0 & 82.50 \\
\hline & 1.5 & 4.23 & 3.10 & 3.66 & 100.00 & 95.00 & 97.50 \\
\hline & & 3.62 & 2.45 & & 78.10 & 73.33 & \\
\hline LSD at $5 \% \mathrm{~A}$ & & & 0.36 & & & 4.30 & \\
\hline B & & & 0.19 & & & 2.29 & \\
\hline $\mathrm{AxF}$ & & & 0.15 & & & 6.08 & \\
\hline
\end{tabular}

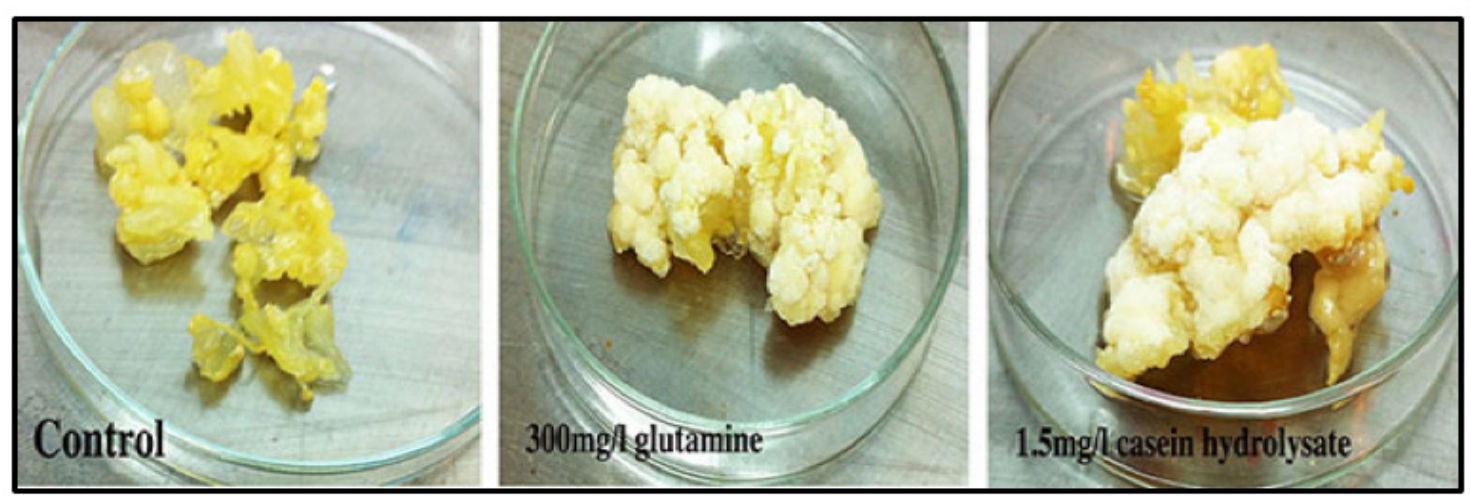

Fig. 2. Callus induction from juice vesicles on MS medium supplemented with 2mg// 2, 4-D after two months from cultured . 
TABLE 3. Effect of different concentrations of coconut water and explant types (juice vesicles and cotyledons) on callus fresh weight (g) and callus percentage. (Observations recorded after two months for two times).

\begin{tabular}{|c|c|c|c|c|c|c|}
\hline \multirow{3}{*}{$\begin{array}{l}\text { Coconut water } \\
(\mathbf{v} / \mathbf{v} \%)\end{array}$} & \multicolumn{3}{|c|}{ Fresh weight of callus (g) } & \multicolumn{3}{|c|}{ Callus (\%) } \\
\hline & \multicolumn{6}{|c|}{ Explant type } \\
\hline & $\begin{array}{c}\text { Juice } \\
\text { vessels }\end{array}$ & Cotyledons & Mean (B) & $\begin{array}{c}\text { Juice } \\
\text { vessels }\end{array}$ & Cotyledons & Mean \\
\hline 0 & 2.48 & 1.13 & 1.80 & 13.33 & 11.66 & 12.50 \\
\hline 5 & 3.06 & 2.93 & 2.99 & 65.00 & 75.00 & 70.00 \\
\hline 10 & 7.96 & 4.23 & 5.60 & 100.00 & 90.00 & 95.00 \\
\hline 20 & 6.03 & 3.25 & 4.64 & 83.33 & 93.33 & 88.33 \\
\hline Mean (A) & 4.63 & 2.88 & & 65.41 & 67.50 & \\
\hline LSD at $5 \% \mathrm{~A}$ & & 0.55 & & & 6.59 & \\
\hline $\mathrm{B}$ & & 0.38 & & & 4.66 & \\
\hline $\mathrm{AxB}$ & & 0.77 & & & 9.32 & \\
\hline
\end{tabular}

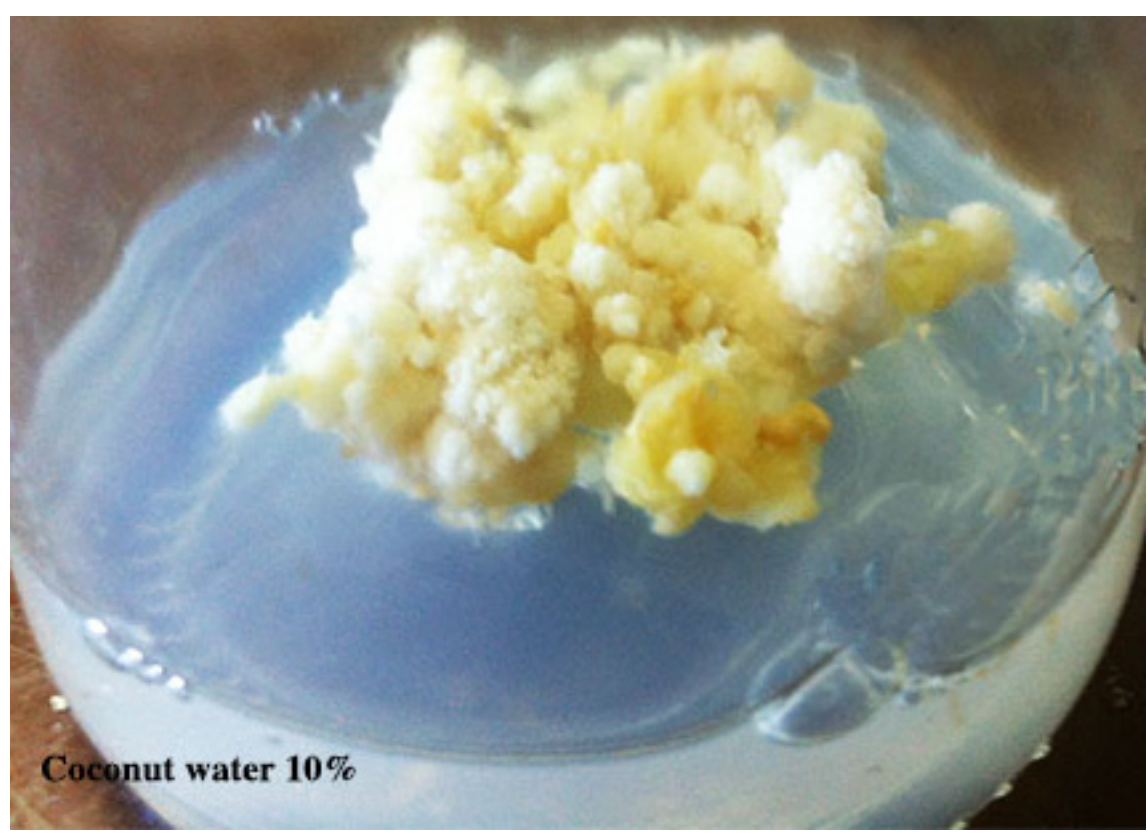

Fig. 3. Improved callus derived juice vesicles on MS supplemented with 2mg/l 2,4-D and $10 \%$ coconut water.

Effect of Malt extract on callus regeneration from callus derived juice vesicles and cotyledons

Malt extract is one of the carbohydrate sources and it has been determined that it stimulate somatic embryogenic callus in citrus. Maximum fresh weight of callus (4.78g/explant) and callus regenerated $(97.50 \%)$ derived from juice vesicles was observed on MS media containing $400 \mathrm{mg} / \mathrm{l}$ malt extract after ten months. However, the results from the current study produced maximum regenerated callus $93.73 \%$ of juice vesicles than derived from cotyledons (82.67\%). Interaction between explant type and different concentration of malt extract showed the highest callus weight and percentage of callus regenerated recorded for juice vesicles at 300 or $400 \mathrm{mg} / \mathrm{l}$ malt extract than other treatments as shown in Table 4. From the result, it showed that, organic compound such as malt extract enhanced callus regeneration only at high concentration of malt extract for mandarin as shown in Fig. 4. Malt extract seems to play a specific role in cultures of mandarin explants. Malt extract, mainly a source of carbohydrates, was shown to callus regenerated in explants. Sawy et al. (2005) reported that the callus induction and somatic somatic embryogenesis formation from undeveloped ovules in citrus by the use of 500 $\mathrm{mg} / \mathrm{l}$ malt extract on MS medium. Malt extract or in combination with GA3 enhance somatic embryogenesis formation in different citrus species (Gholami et al., 2013). Somatic embryos of Mexican lime were formed only by the use of MT medium containing 500 to $700 \mathrm{mg} / 1$ malt extract (Amin \& Shekafandeh, 2015). 
TABLE 4. Effect of MS medium supplemented with $2 \mathrm{mg} / \mathrm{l} 2,4-\mathrm{D}$ and different concentrations of malt extract on weight of callus and callus regeneration from callus raised from juice vesicles and cotyledons.

\begin{tabular}{|c|c|c|c|c|c|c|}
\hline \multirow[b]{3}{*}{$\begin{array}{l}\text { Malt extract con. } \\
\text { mg/l }\end{array}$} & \multicolumn{3}{|c|}{ Callus weight (g) } & \multicolumn{3}{|c|}{ Callus regeneration \% } \\
\hline & \multicolumn{6}{|c|}{ Explant type } \\
\hline & $\begin{array}{c}\text { Juice } \\
\text { vesicles }\end{array}$ & Cotyledons & Mean & $\begin{array}{c}\text { Juice } \\
\text { vesicles }\end{array}$ & Cotyledons & Mean \\
\hline Control & 2.82 & 1.53 & 2.17 & 80.33 & 61.67 & 71.00 \\
\hline 100 & 4.43 & 1.90 & 3.16 & 93.33 & 80.00 & 86.66 \\
\hline 200 & 4.83 & 1.98 & 3.40 & 95.00 & 83.33 & 89.16 \\
\hline 300 & 5.08 & 3.10 & 4.09 & 100.00 & 93.33 & 96.66 \\
\hline 400 & 5.66 & 3.91 & 4.78 & 100.00 & 95.00 & 97.50 \\
\hline Mean & 4.56 & 2.48 & & $93.73 \mathrm{~A}$ & 82.67 & \\
\hline LSD at $5 \% \mathrm{~A}$ & & 0.37 & & & 3.27 & \\
\hline B & & 0.23 & & & 2.07 & \\
\hline $\mathrm{AxB}$ & & 0.52 & & & 4.62 & \\
\hline
\end{tabular}
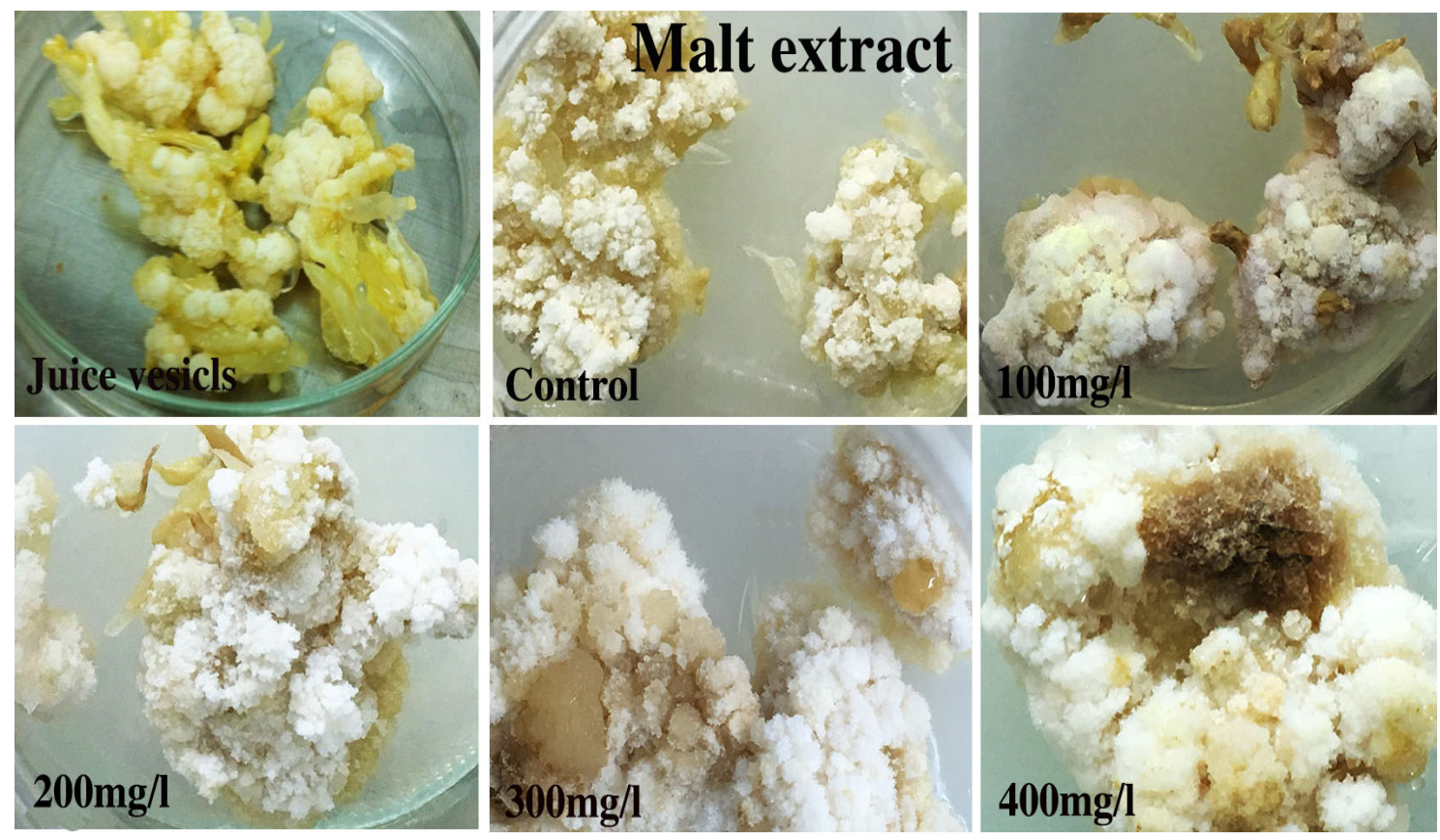

Fig. 4. Callus regeneration from juice vesicles in MS supplemented with 2mg/l 2,4-D and different concentration of malt extract.

Effect of different concentration of NAA on in direct organogenesis from callus derived juice vesicles and cotyledons

The results indicated that good shoots induction was obtained from highest concentration $2.0 \mathrm{mg} / \mathrm{l} \mathrm{NAA}$ in both explants (Table 5). In direct organogenesis increases with the increase of hormonal level (Fig. 5). It was interesting to note that response of both explant type was almost similar at other 2 concentrations level of NAA. According to the results, NAA has maximum shoots formation, due to the presence of auxins at $2 \mathrm{mg} / \mathrm{l}$ NAA from callus derived from juice vesicles than cotyledons, this depends on its concentration. NAA at low concentration showed a progressive increase in shoots percentage. These results got support from Tomaz et al. (2001) showed that the enhancing effects of auxins (NAA and BAP) on embryos formation percentage in citrus and significant results for embryos. Maximum plantlets were regenerated (92\%) from the somatic embryos on half strength MS medium with no hormones (Hussain et al., 2016). 
TABLE 5. Effects of MS medium supplemented with $0.5 \mathrm{mg} / \mathrm{l} \mathrm{Kin,} 400 \mathrm{mg} / \mathrm{l}$ malt extract and different concentrations of NAA on percentage of shoots induction percentage from callus (derived from juice vesicles and cotyledons).

\begin{tabular}{|c|c|c|c|}
\hline \multirow[b]{2}{*}{$\begin{array}{l}\text { Supplement (mg/l) } \\
\text { NAA }\end{array}$} & \multicolumn{3}{|c|}{ Shoots induction \% } \\
\hline & $\begin{array}{c}\text { Regeneration from juice } \\
\text { vesicles callus }\end{array}$ & $\begin{array}{l}\text { Regeneration from } \\
\text { cotyledons callus }\end{array}$ & Mean \\
\hline Control & 23.33 & 20.00 & 21,66 \\
\hline 0.5 & 63.33 & 48.33 & 54.83 \\
\hline 1.0 & 66.67 & 53.33 & 60.00 \\
\hline 1.5 & 76.67 & 56.67 & 66.66 \\
\hline 2.0 & 96.67 & 68.33 & 82.49 \\
\hline Mean & 65.33 & 48.33 & \\
\hline L.S.D at $5 \% \mathrm{~A}$ & & 2.82 & \\
\hline B & & 1.78 & \\
\hline $\mathrm{AxB}$ & & 4.00 & \\
\hline
\end{tabular}
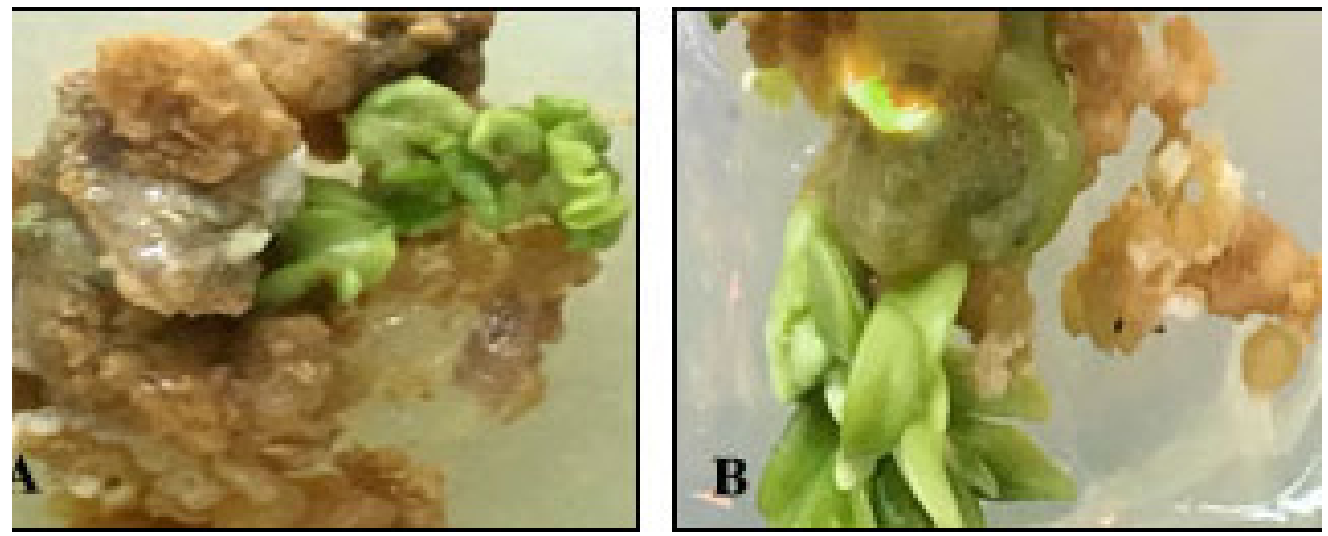

Fig. 5. In direct shoots formation from callus derived juice vesicles on MS medium supplemented with 2mg/l NAA, $0.5 \mathrm{mg} / \mathrm{l}$ Kin and $400 \mathrm{mg} / \mathrm{l}$ malt extract. A: initiation of shoots formation. B: Developed shoots.

Effect of $2 \mathrm{mg} / \mathrm{l}$ BA combination with different NAA concentration on shoot regeneration

The shoots were obtained from above experiment used for shoot regeneration. Amongst various concentration of the four NAA at the concentration of 0.2 and $0.4 \mathrm{mg} / \mathrm{l}$ induced maximum number of shoots (49.00) per explant (Fig. 6). The proliferated shoots reached to a maximum plant height $(2.90 \mathrm{~cm})$ on MS medium supplemented with 0.2 and $0.4 \mathrm{mg} / \mathrm{l} \mathrm{NAA} \mathrm{mg/l}$ (Fig. 7). The shoots obtained from $2 \mathrm{mg} / \mathrm{l} \mathrm{BA}$ supplemented medium were having less number of shoots as compared to shoots obtained on $2 \mathrm{mg} / \mathrm{l} \mathrm{BA}$ and combination with NAA at different concentration. From the result, add $2 \mathrm{mg} / 1 \mathrm{BA}$ resulted in increased shoot number while BA combination with $0.2 \mathrm{mg} / \mathrm{l}$ NAA increased and improved shoots clearly (Fig. 8).
Higher NAA levels with BA combination showed highest positive effects on shoots number and shoots length. The results are consistent with those of Tallon et al. (2013) and Esmaeilnia \& Dehestani (2015). Amgai et al. (2016) found that shooting from explants was significantly higher $(71.72 \%)$ on medium level of the BAP $(0.5 \mathrm{mg} / \mathrm{L})$ and IAA $(0.2 \mathrm{mg} / \mathrm{L})$ using in-vitro seedling stem as explant of mandarin orange.

\section{Effect of auxin concentration on in vitro rooting}

MS medium supplemented with $2 \mathrm{mg} / 1$ NAA induced roots (Fig. 9). NAA has previously been used for induction of roots from in vitro regenerated shoots of citrus. Root induction was observed 15-20 days after transfer of shoots to MS medium. The results indicate that NAA concentration supplied to MS medium, significantly influenced root induction and shoot 
growth. The best rooting treatment was $2 \mathrm{mg} / 1$ NAA, since it gave the highest root number, root length, leaves number and percentage of root induction. Root number increased fourfold in response to $2 \mathrm{mg} / 1$ NAA compared to the hormonefree control, but lower levels of IBA reduced root number, as illustrated in Table 6. In contrast, root length was directly related to the concentration of NAA. The longest roots, $5.5 \mathrm{~cm}$, were found in media containing $2 \mathrm{mg} / \mathrm{l} \mathrm{NAA}$. To encourage root development, it may be advantageous to transfer shoots from root induction on $2 \mathrm{mg} / 1 \mathrm{NAA}$, which gave the highest root number, root length, leaves number and percentage of root induction. The plants were successfully transferred to pots in a greenhouse with $98 \%$ survival percentage. Similarly, Highest rooting percentage in (Citrus aurantifolia and Citrus sinensis) was obtained at concentration of $1.5 \mathrm{mg} / 1$ NAA (Mukhtar et al., 2005). Eight weeks after incubation of embryos on MS medium supplemented with $0.02 \mathrm{mg} / 1$ NAA and different levels of GA3 $(0,0.25,0.5$, 0.75 and $1.0 \mathrm{mg} / \mathrm{l})$ plantlets were then transferred into pots containing of $1: 2: 2$ volume ratios of soil mixture (sand, peat moss and perlite, respectively) and the rate of survival was $100 \%$ of mexican lime (Amin \& Shekafandeh, 2015). The highest rooting rates of 76 and $72 \%$ were recorded for media supplemented with 0.5 or $1 \mathrm{mg}$ L-1 NAA, respectively for sweet orange (Citrus sinensis L. Osbeck.) (Esmaeilnia \& Dehestani, 2015).

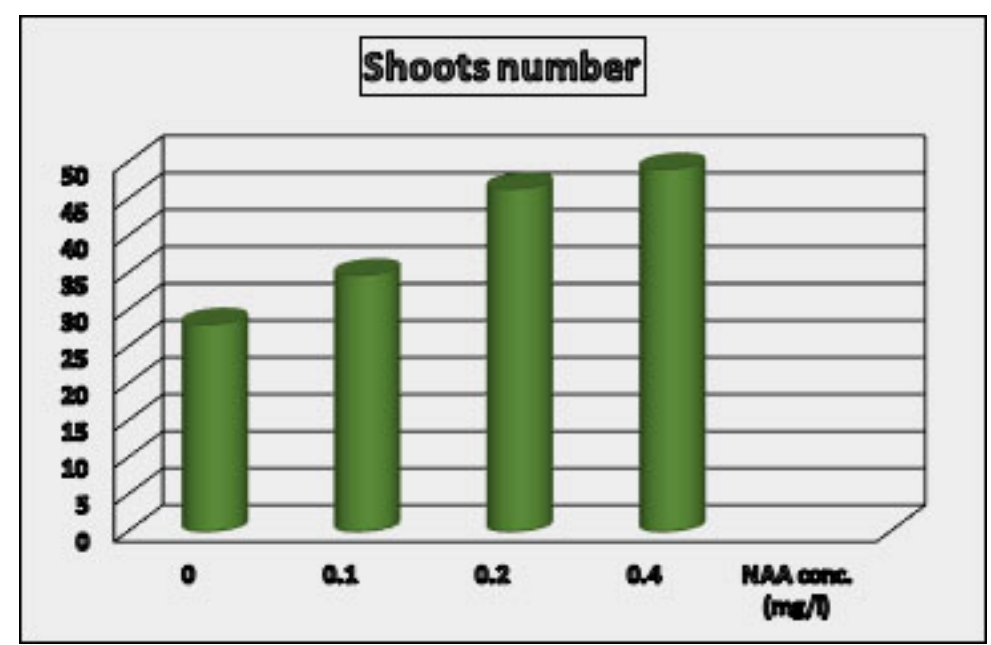

Fig. 6. Effect of different concentrations of NAA and combination with $2 \mathrm{mg} / \mathrm{l}$ BA on shoots number after four weeks from culture.

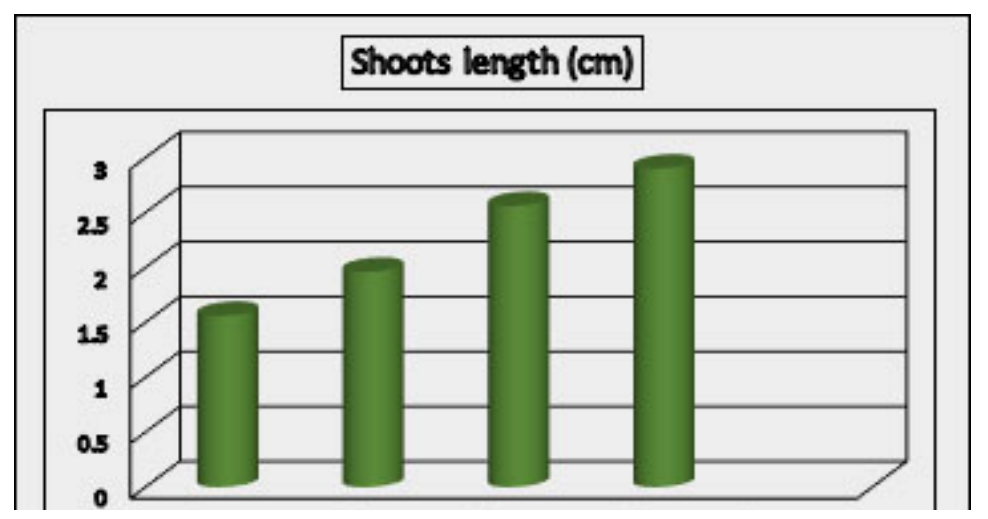

Fig. 7. Effect of different concentrations of NAA and combination with $2 \mathrm{mg} / \mathrm{l}$ BA on shoots length after four weeks. 


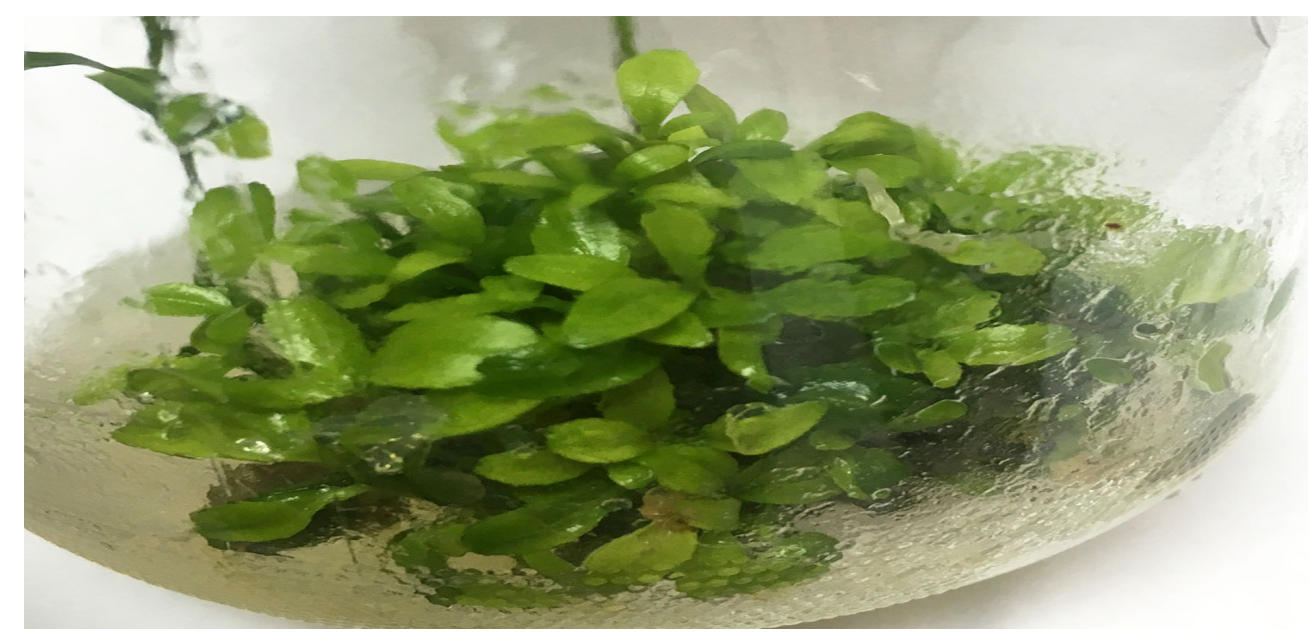

Fig. 8. Development of shoots on MS medium supplemented with $2 \mathrm{mg} / \mathrm{l}$ BA and combination with $0.2 \mathrm{mg} / \mathrm{l}$ NAA.
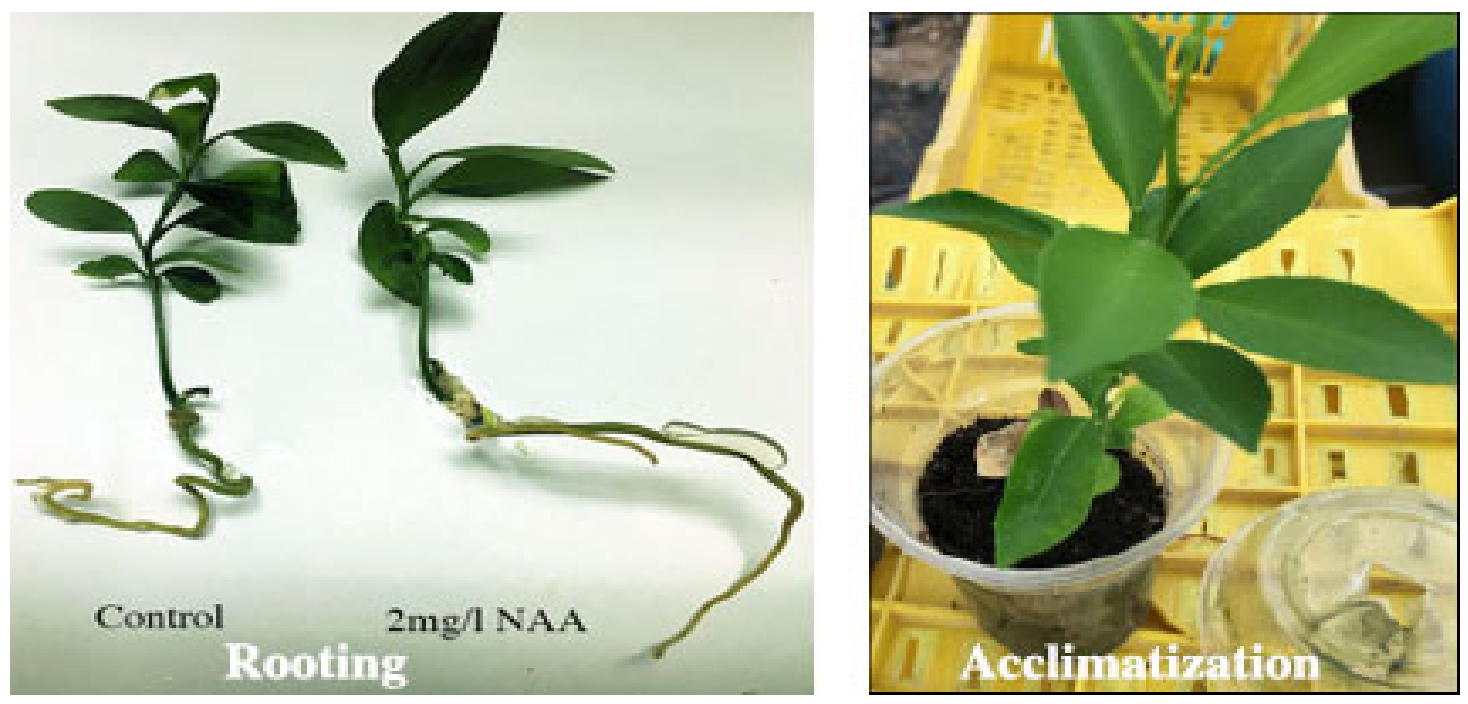

Fig. 9. In vitro rooting and ex vitro acclimatization of mandarin (Citrus reticulate $\mathrm{L}$.$) .$

TABLE 6. Effect of MS supplemented with different concentrations of NAA and IBA on roots number, roots length, leaves number and rooting percentage of (Citrus reticulata $\mathrm{L}$.).

\begin{tabular}{lccccc}
\hline \multirow{2}{*}{ Auxin con. Mg/l } & & Roots number & Roots length $(\mathbf{c m})$ & Leaves number & Rooting \% \\
\hline \multirow{2}{*}{ NAA } & 0.0 & 1.00 & 2.50 & 10.33 & 35.55 \\
& 0.5 & 2.00 & 3.16 & 11.00 & 67.78 \\
& 1.0 & 2.66 & 4.50 & 12.00 & 83.66 \\
& 1.5 & 3.33 & 4.16 & 12.67 & 88.33 \\
IBA & 2.0 & 4.66 & 5.50 & 14.33 & 98.00 \\
& 0.5 & 1.33 & 3.00 & 8.00 & 66.67 \\
L.S.D at 5 \% & 1.0 & 2.33 & 3.33 & 9.33 & 68.89 \\
& 1.5 & 2.66 & 3.56 & 10.00 & 88.55 \\
& 2.0 & 3.33 & 3.36 & 11.00 & 3.46 \\
\hline
\end{tabular}




\section{Conclusion}

In the present investigation, it has induction of multiple shoot buds from callus mass of juice vesicles explants provided a novel protocol for in direct propagation of Citrus mandarin in tissue culture. It resulted in the regeneration of a large number of plantlets from single explants. This technique, therefore, is an efficient system for germplasm conservation and mass multiplication of this important fruit plant, as compared to propagation by seed.

\section{References}

Altaf, N. and Khan, A.R. (2009) In vitro culture of kinnow explants. Pak. J. Bot. 41(2), 597-602.

Amgai, R.B., Prasai, H.K. and Pandey, Y.R. (2016) Hormonal effect on mandarin orange (Citrus reticulata Blanco) micro-propagation. Nepal Journal of Biotechnology, 4(1), 33-36

Amin, H. and Shekafandeh, A. (2015) Somatic embryogenesis and plant regeneration from juice vesicles of mexican lime (Citrus aurantifolia L.). Jordan Journal of Agricultural Sciences, 11(2), 495-505.

Benelli, C., Germana, M.A., Ganino, T. and Beghe, D. (2010) Morphological and anatomical observations of abnormal somatic embryos from anther cultures of Citrus reticulata. Biologia Plantarum, 54(2), 224-230.

Carimi, F., DE Pasquale, F. and Puglia, A.M. (1998) In vitro rescue of zygotic embryos of sour orange, Citrus aurantium L., and their detection based on RFLP analysis. Plant Breeding, 117, 261-266.

Esmaeilnia, E. and Dehestani, A. (2015) In vitro plant regeneration from mature tissues of thomson navel sweet orange (Citrus sinensis L. Osbeck.). Biharean Biologist, 9(1), 9-14.

Gholami, A.A., Alavi, S.V., Majd, A. and Fallahian, F. (2013) Plant regeneration through direct and indirect somatic embryogenesis from immature seeds of citrus. Europ. J. Expt. 3(3), 307-310.

Hussain, M., Raja, N.I., Iqbal, M., Iftikhar, A., Sadaf, H.M., Sabir, S., Sultan, M.A., Nasim, M. and Faz, A. (2016) Plantlets regeneration via somatic embryogenesis from the nucellus tissues of kinnow mandarin (Citrus reticulata L.). American Journal of Plant Sciences, 7, 798-805.

Kiong, A.L.P., Wan, L.S., Hussein, S. and Ibrahim, R. (2008) Induction of somatic embryos from different explants of Citrus sinensis. Journal Plant Sci. 3(1), 18 -32.

Ladaniya, M.S. (2008) "Citrus Fruit Biology, Technology and Evaluation". Elsevier Inc.
Mahadi, Syafi'i, I. W. and Sari, Y. (2016) Callus induction of calamansi (Citrus microcarpa) Using 2,4-D and BAP hormones by in vitro methods. JIPI, 21 (2), 84-89

Michael, P. S. (2007) Micropropagation of elite sugarcane planting materials from callus culture in vitro; The Journal and the Proceedings of the Royal Society of New South Wales, 140 (3\&4), 79-86.

Michael, P. S (2011) Effects of coconut water on callus initiation and plant regeneration potentials of sweet potato. Journal and Proceedings of the Royal Society of New South Wales,. 144(3\&4), 91-101.

Mukhtar, R., Khan, M. M., Rafiq, R., Shahid, A. and Khan, F.A. (2005) In vitro regeneration and somatic embryogenesis in (Citrus aurantifolia and Citrus sinensis). International Journal of Agriculture and Biology, 7(3), 518-520.

Murashige, T. and Skoog, F. (1962) A revised medium for rapid growth and bioassays with tobacco tissue cultures. Physiol. Plant, 15, 473-497.

Nasir, I.A., Jahangir, G.Z., Qamar, Z., Rahman, Z. and Husnain, T. (2011) Maintaining the regeneration potential of sugarcane callus for longer span. Afr. $J$. Agric. Res. 6(1), 113-119.

Niaz, A.C., Maken, M.N. and Malik, S.A. (2004) Native home, historical background and importance of citrus Fruits in Pakistan. Proceedings of the $1^{\text {st }}$ International Conference on Citriculture, University of Agriculture Faisalabad, pp.48-56.

Nito, N. and Iwamasa, M. (1990) In vitro plantlet formation from juice vesicle callus of satsuma (Citrus unshiu Marc.). Plant Cell Tissue Org. Cult. 20, 137-140

Sawy, A. El, Gomaa, A., Reda, A. and Danial, N. (2005) Somatic embryogenesis and plant regeneration from undeveloped ovules of Citrus. Arab J. Biotech. 9(1), 189-202.

Schinor, E. H., DE Azevedo, F. A., Assis, F. DE, Filho, A. M. and Mendes, B. M. J. (2011) In vitro organogenesis in some citrus species. Rev. Bras. Frutic., Jaboticabal SP, 33(2), 526-531.

Starrantino, A. and Russo, F, (1980) Seedlings from undeveloped ovules of ripe fruits of polyembryonic citrus cultivars. Hort. Science, 15, 296-297.

Steel, R. G. D. and Torrie (1980) "Principals and Procedure of Statistics" ( $2^{\text {nd }}$ ed.). Mc. Graw Hill.

Tallon, C.I., Porras, I. and Perez-Tornero, O. (2013) High efficiency in vitro organogenesis from mature tissue explants of Citrus macrophylla and C. aurantium. In vitro Cellular and Developmental Biology - Plant, 49, 145-155.

Tomaz, M., Mendes, B.J., Filho, A.M. and Rodrigues, P.M. (2001) Somatic embryogenesis in citrus species. In vitro Cell and Dev. Biol. 37, 446-52. 
Usman, M. (2005) Plant propagation and improvement, in: "Citrus Nursery Raising: Principles and Practices". Usman M. and Abbas M. (Ed.), pp.2366, Mass Pub., Pakistan, .

Widoretno, W., Indriyani, S., Martasari, C. and Hakin, R. ( 2017) Effects of sugar type and concentration on Batu 55 Mandarin (Citrus reticulata Blanco.) somatic embryo maturation. AGRIVITA Journal of Agricultural Science, 39(1), 100-110.
Xiao, J.N., Huang ,X.L., Wu, Y.J., Li, X.J, Zhou, M.D. and Engelmann, F. (2004) Direct somatic embryogenesis induced from cotyledons of Mango immature zygotic embryos, In vitro Cell Dep. Biol. Plant, 40, 196-199.

Yong, J.W.H., Ge, L., Ng, Y.F. and Tan, S.N. (2009) The chemical composition and biological properties of coconut (Cocos nucifera L.) water. Molecules, 14, 5144-5164.

(Received 24/3/2017; accepted 27/4/2017)

\section{تأسيس نظام الاكثار الغير مباشر لليوسفي ( Citrus reticulate L) باستخدام زراعة الانسجة}

